\title{
Pengaruh Penyaluran Kredit dan Pendapatan Bunga terhadap Profitabilitas Pada KPRI-UNM di Kota Makassar
}

\author{
Abd. Rijal ${ }^{\text {* }}$, Samsinar ${ }^{2}$, Nurjannah ${ }^{3}$ \\ ${ }^{123}$ Fakultas Ekonomi, Universitas Negeri Makassar \\ 1email : abd.rijal@unm.ac.id, ${ }^{2}$ email : samsinar.anwar@gmail.com, \\ 3email : nurjannahfe@unm.ac.id \\ *Corresponding author
}

\begin{abstract}
This research aims to determine how much influence the credit lending and interest income to profitability on KPRI-UNM. The variables in this research were the distribution of credit (X1), interest income (X2) and profitability (Y). The population included all financial statements on KPRI-UNM in Makassar city and the sample in this research was financial statements on KPRI UNM for the last three years from 2016 until 2018. Data collection techniques used documentation and interviews. Data analysis techniques used Multiple Linear Regression Analysis, T-Test, and F-Test. The results of this research showed that the distribution of credit and interest income partially and simultaneously had a significant effect on profitability.
\end{abstract}

Keywords. Credit Lending; Interest Income; Profitability

\begin{abstract}
Abstrak. Penelitian ini bertujuan untuk mengetahui seberapa besar pengaruh penyaluran kredit dan pendapatan bunga terhadap profitabilitas pada KPRI-UNM. Variabel dalam penelitian ini adalah penyaluran kredit (X1), Pendapatan bunga (X2) dan Profitabilitas (Y). Populasinya meliputi keseluruhan laporan keuangan pada KPRI-UNM di kota Makassar dan sampel penelitian ini adalah laporan keuangan KPRI-UNM selama tiga tahun terakhir dari tahun 2016 sampai tahun 2018. Teknik pengumpalan data yang digunakan adalah dokumentasi dan wawancara. Teknik analisis data yang di gunakan dalam penelitian ini yaitu Analisis Regresi Linear Berganda, Uji-t dan Uji-f. Hasil penelitian menunjukkan bahwa penyaluran kredit dan pendapatan bunga secara parsial dan simultan berpengaruh signifikan terhadap profitabilitas.
\end{abstract}

Kata kunci. Penyaluran Kredit; Pendapatan Bunga; Profitabilitas

\section{PENDAHULUAN}

Koperasi simpan pinjam adalah koperasi yang modalnya diperoleh dari simpanan pokok dan simpanan wajib para anggota koperasi. Modal yang telah terkumpul tersebut disalurkan kepada para anggota dan terkadang juga dipinjamkan kepada orang lain yang bukan anggota yang memerlukan pinjaman uang, baik untuk keperluan konsumtif maupun untuk modal kerja. Eksistensi koperasi simpan pinjam akan terjamin apabila kinerja usaha yang ditujukkan oleh pertumbuhan usaha yang signifikan didukung kuat oleh adanya aturan atau kebijakan yang baik serta praktikpraktik yang sehat dalam rangka menigkatkan kemampuan ekonomi dan pendapatan anggota.
Penyaluran kredit adalah penyediaan uang atau tagihan berdasarkan persetujuan atau kesepakatan pinjam meminjam antara koperasi simpan pinjam dengan pihak peminjam yakni anggota koperasi yang mewajibkan pihak peminjam untuk melunasi kewajibannya setelah jangka waktu tertentu.

Bunga merupakan unsur atau komponen pendapatan terbesar koperasi simpan pinjam pendapatan bunga akan berbanding lurus dengan kredit yang disalurkan, bila kredit yang disalurkan semakin besar maka semakin besar pula pendapatan yang akan diterima oleh koperasi simpan pinjam, begitupula sebaliknya semakin sedikit kredit yang disalurkan maka 
semakin sedikit pula pendapatan yang akan diterima. Pendapatan yang diterima melalui penyaluran kredit berupa pendapatan bunga digunakan untuk pembiayaan aktivitas operasional, maka dari itu dibutuhkan rasio profitabilitas untuk mengukur kemampuan perusahaan dalam mencari keuntungan, rasio yang dimaksud adalah rasio profitabilitas. Menurut Kasmir (2002;196), "Rasio Profitabilitas merupakan rasio untuk menilai kemampuan perusahaan dalam mencapai keuntungan".

Profitabilitas suatu perusahaan akan mempengaruhi kebijakan para investor atas investasi yang dilakukan. Kemampuan perusahaan untuk menghasilkan laba dapat menarik para investor untuk menanamkan dananya guna memperluas usahanya. Profitabilitas perusahaan merupakan salah satu dasar penilaian kondisi suatu perusahaan yang menunjukkan apakah badan usaha tersebut mempunyai prospek yang baik di masa yang akan datang. Semakin besar penyaluran kredit suatu perusahaan semakin besar pula tingkat keuntungan yang dicapai sehingga profitabilitas lebih meningkat.

\section{METODE PENELITIAN}

Penelitian ini dilakukan di KPRI-UNM kota Makassar. Dalam penelitian bertujuan mengetahui seberapa besar pengaruh penyaluran kredit dan pendapatan bunga terhadap profitabilitas pada KPRI-UNM. Populasi dalam penelitian ini adalah keseluruhan laporan keuangan pada KPRIUNM di kota Makassar. Teknik penentuan sampel yang digunakan dalam penelitian ini adalah purposive sampling. Adapun yang menjadi sampel dalam penelitian ini adalah laporan keuangan KPRI-UNM selama tiga tahun terakhir dari tahun 2016 sampai tahun 2018.

Teknik pengumpulan data yang digunakan dalam penelitian ini, yaitu: Teknik dokumentasi adalah laporan keuangan selama tiga tahun terakhir (2016-2018), gambaran umum atau latar belakang KPRI-UNM, dan struktur organisasi KPRI-UNM.

Data atau informasi yang diperoleh dari KPRI-UNM yang berhubungan dengan penelitian ini dianalisis dengan menggunakan ROA (Return on Asset) kemudian untuk mengetahui pengaruh ketiga variabel, maka digunakan analisis regresi linear berganda, uji t, dan uji $\mathrm{F}$.

\section{HASIL DAN PEMBAHASAN Penyajian Data}

1. Penyaluran kredit

Data mengenai tingkat penyaluran kredit KPRI-UNM tahun 2016 - 2018 dapat dilihat pada tabel berikut :

Tabel 1. Tingkat penyaluran kredit KPRI-UNM Tahun 2016-2018

\begin{tabular}{ccc}
\hline Tahun & $\begin{array}{c}\text { Penyaluran Kredit } \\
(\mathrm{Rp})\end{array}$ & $\begin{array}{c}\text { Perkem- } \\
\text { bangan }(\%)\end{array}$ \\
\hline 2016 & 45.598 .211 .600 & \\
2017 & 33.115 .650 .000 & $-27,38$ \\
2018 & 29.581 .700 .000 & $-10,67$ \\
\hline
\end{tabular}

Sumber: Laporan Keuangan KPRI-UNM Tahun 2016-2018 (Data diolah)

Berdasarkan tabel 1 dapat diketahui bahwa jumlah penyaluran kredit selama tiga tahun (2016-2018) mengalami penurunan setiap tahunnya. Pada tahun 2017 terjadi penurunan penyaluran kredit sebesar $27,38 \%$ dari tahun sebelumnya, begitupula pada tahun 2018 kembali mengalami penurunan sebesar $10,67 \%$ yaitu sebesar Rp 29.581.700.000.

2. Pendapatan Bunga

Dalam laporan KPRI UNM pendapatan bunga yang dimaksud adalah pendapatan bunga piutang simpan pinjam. 
Tabel 2. Pendapatan bunga KPRI-UNM Tahun 2016-2018

\begin{tabular}{ccc}
\hline Tahun & Pendapatan Bunga $(\mathrm{Rp})$ & Perkembangan $(\%)$ \\
\hline 2016 & 12.574 .056 .043 & \\
2017 & 11.262 .353 .495 & $-10,43$ \\
2018 & 9.475 .788 .267 & $-15,86$ \\
\hline
\end{tabular}

Sumber: Laporan Keuangan KPRI-UNM Tahun 2016-2018 (Data diolah)

Dari tabel 2 di atas dapat dilihat bahwa pendapatan bunga pada KPRI UNM mengalami penurunan dari tahun ke tahun. Pada tahun 2017 mengalami penurunan sebesar $10,43 \%$ dari tahun sebelumnya, begitupula pada tahun 2018 kembali mengalami penurunan sebesar $15,86 \%$ yaitu sebesar Rp 9.475.788.267 dan menjadi pendapatan bunga terendah dari tiga tahun terakhir.

3. Profitabilitas

Dalam penelitian ini, Rasio profitabilitas yang digunakan yaitu ROA (Return On Assets) dengan cara membandingkan laba bersih dengan total aset. Berikut ini disajikan data mengenai laba bersih dan total aset KPRI UNM tahun 2016 - 2018.

Tabel 3. Laba bersih dan total aset KPRI-UNM Tahun 2016 -2018

\begin{tabular}{ccc}
\hline Tahun & $\begin{array}{c}\text { Laba Bersih } \\
(\mathrm{Rp})\end{array}$ & $\begin{array}{c}\text { Total Asset } \\
(\mathrm{Rp})\end{array}$ \\
\hline 2016 & 466.935 .288 & 900.984 .912 .470 \\
2017 & 479.909 .772 & 938.916 .496 .120 \\
2018 & 489.488 .758 & 986.189 .359 .048 \\
\hline
\end{tabular}

Sumber: Laporan Keuangan KPRI-UNM Tahun 2016-2018 (Data diolah)

Berdasarkan hasil keseluruhan perhitungan profitabilitas dengan menggunakan analisis ROA selama tiga tahun terakhir KPRI
UNM, dapat dilihat pada tabel rekapitulasi hasil penelitian profitabilitas dengan menggunakan analisis ROA (Return On Aset) berikut ini:

Tabel 4. Profitabilitas dengan menggunakan analisis ROA KPRI-UNM Tahun 2016 - 2018

\begin{tabular}{ccc}
\hline Tahun & ROA (\%) & Perkembangan $(\%)$ \\
\hline 2016 & 0,050 & $-1,37$ \\
2017 & 0,051 & $-2,89$ \\
2018 & 0,050 &
\end{tabular}

Sumber: Laporan Keuangan KPRI-UNM Tahun 2016-2018 (Data diolah)

Berdasarkan data pada tabel 4 , dapat dilihat bahwa Return On Aset KPRI UNM mengalami penurunan dari tahun ke tahun. Pada tahun 2017, nilai ROA mengalami penurunan sebesar $1,37 \%$ dari $0,052 \%$ menjadi $0,051 \%$, Sama halnya tahun 2017, pada tahun 2018 terlihat bahwa total laba bersih meningkat diikuti dengan peningkatan total aset, namun persentase peningkatan laba bersih dari tahun sebelumnya hanya sebesar $2,00 \%$, sementara persentase peningkatan total aset nya sebesar
$5,03 \%$, yang artinya pada tahun 2018 persentase perkembangan laba bersih lebih kecil dibandingkan persentase perkembangan total aset.

4. Analisis Pengaruh Penyaluran Kredit dan Pendapatan Bunga terhadap Profitabilitas pada KPRI UNM tahun 2016-2018

Berikut ini disajikan data mengenai variabel-variabel yang diteliti, yaitu penyaluran kredit,pendapatan bunga, dan profitabitas pada KPRI UNM 
Tabel 5. Data penyaluran kredit, pendapatan bunga, dan profitabilitas pada KPRI-UNM

Tahun 2016-2018

\begin{tabular}{cccc}
\hline Tahun & Penyaluran Kredit (Rp) & Pendapatan Bunga (Rp) & $\begin{array}{c}\text { Profitabilitas } \\
\text { ROA }(\%)\end{array}$ \\
\hline 2016 & 45.598 .211 .600 & 12.574 .056 .043 & 0,052 \\
2017 & 33.115 .650 .000 & 11.262 .353 .495 & 0,051 \\
2018 & 29.581 .700 .000 & 9.475 .788 .267 & 0,050 \\
\hline
\end{tabular}

Sumber: Laporan Keuangan KPRI-UNM Tahun 2016-2018 (Data diolah)

\section{Analisis Regresi Linear Berganda}

Analisis ini digunakan untuk mengetahui seberapa besar pengaruh variabel bebas (independen) terhadap variabel terikat (dependen) baik secara bersama-sama (simultan) maupun secara parsial. Dalam penelitian ini, untuk mengetahui seberapa besar pengaruh antara penyaluran kredit (X1) dan pendapatan bunga (X2), terhadap Profitabilitas (Y). Ringkasan hasil analisis regresi linear berganda dapat dilihat pada tabel berikut:

Tabel 6. Hasil Analisis Regresi Linear Berganda

\begin{tabular}{|c|c|c|c|c|c|}
\hline \multirow[b]{3}{*}{ Model } & \multicolumn{3}{|c|}{ Coefficients $^{\mathrm{a}}$} & \multirow[b]{3}{*}{$\mathrm{T}$} & \multirow[b]{3}{*}{ Sig. } \\
\hline & $\begin{array}{r}\text { Unst } \\
\mathrm{Co}\end{array}$ & $\begin{array}{l}\text { dardized } \\
\text { ficients }\end{array}$ & $\begin{array}{c}\text { Standardized } \\
\text { Coefficients }\end{array}$ & & \\
\hline & B & Std. Error & Beta & & \\
\hline 1 (Constant) & -9.594 & 3.742 & & -2.564 & 0.015 \\
\hline Penyaluran kredit & -0.623 & 0.283 & -0.342 & -2.205 & 0.035 \\
\hline Pendapatan Bunga & 1.735 & 0.435 & 0.619 & 3.990 & 0.000 \\
\hline
\end{tabular}

Dependent Variable: Profitabilitas

Sumber: Hasil olah SPSS, 2019

Berdasarkan tabel 6, diketahui bahwa dua variabel independen yaitu penyaluran kredit dan pendapatan bunga memiliki profitabilitas signifikan masing-masing 0,035 dan 0,000 yang signifikan dengan 0,05 oleh sebab itu dapat disimpulkan bahwa variabel Profitabilitas dipengaruhi oleh penyaluran dana dan pendapatan bunga dengan persamaan regresi berganda sebagai berikut :

$$
\begin{aligned}
& Y=a+b \_1 X \_1+b \_2 X \_2 \\
& Y=-9,594-0,623 X \_1+0,1735 X \_2
\end{aligned}
$$

Penjelasan persamaan regresi tersebut adalah:

1. Konstanta $(\mathrm{a} 0)=-9,594$ ini menunjukkan bahwa jika variabel penyaluran kredit dan pendapatan bunga dianggap sama dengan nol, maka variabel profitabilitas sebesar 9,594.

2. Koefisien penyaluran kredit $(\mathrm{b} 1 \mathrm{X} 1)=-$ 0,623 pada penelitian ini dapat diartikan bahwa variabel penyaluran kredit (X1) berpengaruh negatif profitabilitas (Y). Hal ini menunjukkan bahwa jika variabel penyaluran kredit mengalami kenaikan satu satuan, sementara variabel pendapatan bunga dianggap tetap maka akan menyebabkan penurunan profitabilitas sebesar 0,623 .

3. Koefisien pendapatan bunga $(\mathrm{b} 2 \mathrm{X} 2)=$ 0,1735 pada penelitian ini dapat diartikan bahwa variabel pendapatan bunga (X2) berpengaruh positif terhadap profitabilitas (Y). Hal ini menunjukkan bahwa jika variabel pendapatan bunga mengalami kenaikan satu satuan, sementara variabel penyaluran kredit dianggap tetap maka akan menyebabkan kenaikan profitabilitas sebesar 0,1735 .

\section{Koefisien Determinasi Simultan (R2)}

Koefisien determinasi ini digunakan untuk mengetahui besarnya pengaruh penyaluran kredit dan pendapatan bunga terhadap profitabilitas. Berikut perhitungan koefisien determinasi menggunakan SPSS v.25.00 for windows. 
Tabel 7. Hasil Uji Analisis Koefisien Determinasi (R2)

Model Summary

\begin{tabular}{|c|c|c|c|c|}
\hline Model & $\mathrm{R}$ & R Square & Adjusted R Square & Std. Error of the Estimate \\
\hline 1 & $.576^{\mathrm{a}}$ & 0.332 & 0.291 & 0.24012 \\
\hline
\end{tabular}

a. Predictors: (Constant), Pendapatan Bunga, Penyaluran kredit

b. Dependent Variable: Profitabilitas

Sumber: Hasil olah SPSS, 2019

Dari hasil perhitungan tabel 7 dari pengolaan data SPSS v.25.00 for windows diperoleh nilai $\mathrm{R}$ yaitu 0,576 artinya pengaruh penyaluran kredit dan pendapatan bunga terhadap profitabilitas adalah sebesar 57,6 persen, namun nilai tersebut dapat dikatakan terkontaminasi oleh berbagai nilai penganggu yang mungkin menyebabkan kesalahan pengukuran. Untuk itu nilai $\mathrm{R}$ Square sebagai perbandingan akurasi pengaruhnya. Sedangkan nilai Adjusted R Square yaitu 0,291. Hal ini berarti bahwa pengaruh kontribusi penyaluran kredit dan pendapatan bunga terhadap profitabilitas adalah sebesar 29,1 persen. Nilai adjusted R Square sudah lebih disesuaikan dan lazimnya nilai ini yang lebih akurat. Terlihat bahwa nilai $\mathrm{R}$ Square yaitu sebesar 0,332 . Hal

ini berarti bahwa pengaruh kontribusi penyaluran kredit dan pendapatan bunga terhadap profitabilitas adalah sebesar 33,2 persen. Sedangkan sisanya 66,8 persen dipengaruhi oleh faktor lain yang ikut mempengaruhi dalam penentuan naik atau turunnya profitabilitas karena selain dari penyaluran kredit dan pendapatan bunga masih banyak faktor-faktor lain yang tidak diteliti.

\section{Uji Simultan (Uji F)}

Uji $F$ dilakukan untuk mengetahui penyaluran kredit dan pendapatan bunga terhadap profitabilitas secara bersama-sama atau simultan. Pengolahan data dilakukan menggunakan alat bantu SPSS v.25.00 for windows sebagai berikut:

Tabel 8. Hasil Uji Simultan (Uji F)

\begin{tabular}{lrr|r|r|r|r}
\multicolumn{7}{c}{ ANOVA $^{\mathbf{a}}$} \\
\hline Model & Sum of Squares & Df & Mean Square & F & \multicolumn{1}{c}{ Sig. } \\
\hline 1 & 0.944 & 2 & 0.472 & 8.187 & $.001^{\mathrm{b}}$ \\
\cline { 2 - 8 } & Regression & 1.903 & 33 & 0.058 & & \\
\cline { 2 - 8 } & 2.847 & 35 & & & \\
\hline Residual & &
\end{tabular}

a. Dependent Variable: profitabilitas

b. Predictors: (Constant), pendapatan bunga, penyaluran kredit

Sumber: Hasil olah SPSS, 2019

Berdasarkan tabel 8 diketahui bahwa Fhitung sebesar 8,187 dengan taraf signifikan $0,001 \leq 0,05$. Dan F tabel diperoleh sebesar 3,28 dengan demikian nilai F-hitung sebesar 8,187 lebih besar dibandingkan dengan $\mathrm{F}$ tabel sebesar 3,28 dengan taraf siginifikan sebesar $0,001<0,05$.

Hal ini disimpulkan bahwa hipotesis diterima atau dengan kata lain penyaluran kredit dan pendapatan bunga secara simultan berpengaruh positif dan signifikan terhadap profitabilitas.

\section{Uji Parsial (Uji t)}

Uji-t digunakan untuk mengetahui apakah variabel bebas berpengaruh terhadap variabel terikat secara signifikan atau tidak. Adapun taraf signifikansi pengujian hipotesis yaitu, nilai taraf signifikansi $\leq 0,05$ maka terdapat pengaruh yang signifikan antara variabel bebas (penyaluran kredit dan pendapatan bunga) dengan variabel terikat profitabilitas dan nilai taraf signifikan $\geq 0,05$ maka tidak terdapat pengaruh yang signifikan antara variabel bebas (penyaluran kredit dan pendapatan bunga) dengan variabel terikat 
(return on asset). Hasil uji-t dapat dilihat pada tabel berikut:

Tabel 9. Hasil Uji Parsial (Uji t)

Coefficients $^{\mathbf{a}}$

\begin{tabular}{|c|c|c|c|c|c|}
\hline \multirow[b]{2}{*}{ Model } & \multicolumn{2}{|c|}{$\begin{array}{c}\text { Unstandardized } \\
\text { Coefficients }\end{array}$} & \multirow{2}{*}{$\begin{array}{c}\text { Standardized } \\
\text { Coefficients } \\
\text { Beta } \\
\end{array}$} & \multirow[b]{2}{*}{$\mathrm{t}$} & \multirow[b]{2}{*}{ Sig. } \\
\hline & B & Std. Error & & & \\
\hline $\begin{array}{ll}1 & \text { (Constant) }\end{array}$ & -9.594 & 3.742 & & -2.564 & 0.015 \\
\hline Penyaluran kredit & -0.623 & 0.283 & -0.342 & -2.205 & 0.035 \\
\hline Pendapatan bunga & 1.735 & 0.435 & 0.619 & 3.990 & 0.000 \\
\hline
\end{tabular}

Dependent Variable: profitabilitas

Sumber: Hasil olah SPSS, 2019

Berdasarkan tabel 9, dapat dilihat bahwa pada variabel penyaluran kredit diperoleh nilai t sebesar -2.205 dengan nilai signifikan 0,035. Sedangkan pada variabel pendapatan bunga diperoleh nilai $\mathrm{t}$ sebesar 3.990 dengan nilai signifikan 0,000 dan derajat kebebasan $(\mathrm{dk}=\mathrm{n}-2$ atau $\mathrm{dk}=35-2)$ maka diperoleh nilai $\mathrm{t}$ tabel sebesar 2,034. Kedua variabel memiliki nilai signifikan yang lebih kecil dari alpha yaitu 0,05 maka hipotesis yang menyatakan terdapat pengaruh penyaluran kredit dan pendapatan bunga secara parsial berpengaruh signifikan terhadap profitabilitas diterima.

\section{Pembahasan Hasil Penelitian}

1. Pengaruh Penyaluran Kredit (X1) secara Parsial terhadap Profitabilitas (Y)

Berdasarkan analisis data yang telah dilakukan maka diperoleh hasil bahwa penyaluran kredit berpengaruh negative dan signifikan terhadap profitabilitas. Hal ini sejalan dengan penelitian Setiawati (2013) yang menyatakan bahwa pemberian kredit secara parsial berkorelasi negative dan signifikan terhadap profitabilitas dengan nilai $\mathrm{r}$ square sebesar 0,43 yang artinya penyaluran kredit mempengaruhi profitabilitas sebesar 43 persen.

Hasil uji hipotesis diperoleh secara parsial bahwa penyaluran kredit dengan nilai signifikansi 0,035 < 0,05 maka H0 ditolak dan H1 diterima, berarti penyaluran kredit secara parsial berpengaruh signifikan terhadap profitabilitas pada KPRI UNM di kota Makassar. Dengan demikian, apabila penyaluran kredit yang tinggi, maka akan meningkatkan profitabilitas, begitupun sebaliknya apabila penyaluran kredit rendah maka profitabilitas yang dicapai rendah.

2. Pengaruh Pendapatan Bunga (X2) secara Parsial terhadap Profitabilitas (Y)

Hasil penelitian ini menunjukkan bahwa pendapatan bunga berpengaruh signifikan terhadap profitabilitas. Hal ini sejalan dengan penelitian Setiawati (2013) yang menyatakan bahwa pemberian kredit secara parsial berkorelasi positif dan signifikan terhadap profitabilitas dengan nilai $r$ square sebesar 0,523 yang artinya besarmya kontribusi pendapatan bunga terhadap profitabilitas sebesar 52,3 persen.

Berdasarkan hasil analisis data, diperoleh secara parsial bahwa pendapatan bunga dengan nilai signifikansi $0,000<0,05$ maka H0 ditolak dan $\mathrm{H} 1$ diterima, berarti pendapatan bunga secara parsial berpengaruh signifikan terhadap profitabilitas pada KPRI UNM di kota Makassar. Dengan demikian, apabila pendapatan bunga yang diperoleh tinggi, maka akan meningkatkan profitabilitas, begitupun sebaliknya apabila pendapatan bunga rendah maka profitabilitas yang dicapai rendah.

3. Pengaruh Penyaluran Kredit (X1) dan Pendapatan Bunga (X2) secara Simultan terhadap Profitabilitas (Y)

Berdasarkan penelitian yang telah dilakukan maka diperoleh hasil bahwa Penyaluran kredit (X1) dan pendapatan bunga (X2) secara simultan berpengaruh signifikan terhadap profitabilitas pada KPRI UNM di kota Makassar dengan nilai F-hitung sebesar 8,187 lebih besar dibandingkan dengan $\mathrm{F}$ tabel sebesar 3,28 dengan taraf siginifikan sebesar $0,001<0,05$. Hasil penelitian ini sejalan dengan penelitian Setiawati (2013) yang menyatakan 
bahwa penyaluran kredit dan pendapatan bunga berpengaruh signifikan terhadap terhadap profitabiltas.

Hal ini menunjukkan bahwa penyaluran kredit dan pendapatan bunga berperan penting dalam peningkatan profitabilitas. Hal ini sesuai dengan pendapat Kasmir (2011:125) kredit merupakan unsur utama untuk memperoleh keuntungan. Artinya besarnya laba sangatlah dipengaruhi pendapatan bunga yang diperoleh dari banyaknya kredit yang disalurkan dalam suatu periode. Semakin banyak kredit yang disalurkan, semakin besar pendapatan bunga yang diperoleh, dengan demikian semakin tinggi pula tingkat profitabilitas.

\section{KESIMPULAN DAN SARAN Kesimpulan}

Berdasarkan hasil penelitian pengaruh penyaluran kredit dan pendapatan bunga terhadap profitabilitas pada KPRI UNM di Kota Makassar, maka dapat disimpulkan sebagai berikut :

1. Hasil analisis regresi linear berganda menunjukkan $\hat{\mathrm{Y}}=-9,594-0,623 \mathrm{X} 1+$ $0,1735 \mathrm{X} 2$ yang berarti bahwa ini menunjukkan bahwa jika variabel penyaluran kredit dan pendapatan bunga dianggap sama dengan nol, maka variabel profitabilitas sebesar -9,594. Dan nilai $R$ Square yaitu sebesar 0,332 yang berarti bahwa pengaruh penyaluran kredit dan pendapatan bunga terhadap profitabilitas adalah sebesar 33,2 persen. Sedangkan sisanya 66,8 persen dipengaruhi oleh faktor lain.

2. Hasil uji hipotesis (Uji F) menunjukkan bahwa penyaluran kredit dan pendapatan bunga secara simultan berpengaruh positif dan signifikan terhadap profitabilitas pada KPRI UNM di Kota Makassar. Hal ini terbukti bahwa F_hitung $>$ F_tabel yaitu $8,187>3,28$ yang berarti hipotesis diterima.

3. Hasil uji hipotesis (uji t) menunjukkan bahwa nilai $t$ pada variabel penyaluran kredit sebesar 2,205, dan nili t pada variabel pendapatan bunga sebesar 3,990, dengan 『 t]_tabel sebesar 2,034. Kedua variabel memiliki nilai signifikan yang lebih kecil dari alpha yaitu 0,05 maka hipotesis yang menyatakan terdapat pengaruh penyaluran kredit dan pendapatan bunga secara parsial berpengaruh signifikan terhadap profitabilitas diterima.

\section{Saran}

Berdasarkan hasil penelitian, maka dapat disarankan beberapa hal sebagai berikut :

1. Sebaiknya manajemen KPRI UNM memperhatikan berbagai usaha dalam hal meningkatkan pendapatan bunga karena mempunyai pengaruh yang signifikan terhadap profitabilitas.

2. Bagi peneliti selanjutnya, disarankan agar meneliti variabel lain yang mempengaruhi profitabilitas, dan menggunakan analisis rasio profitabilitas lainnya.

\section{DAFTAR PUSTAKA}

Anwar. 2002. Praktek Perbankan. Jakarta: Ghalia Indonesia.

Baridwan, Zaki. 2004. Intermediate Accounting. Yogyakarta: BPFE.

Dendawijaya, Lukman. 2005. Manajemen Perbankan. Edisi kedua. Jakarta: Ghalia Indonesia.

Fahmi, Irham. 2011. Analisis Kinerja Keuangan. Bandung: Alfabeta.

Harahap, Syafri Sofyan. 2013. Analisis Kritis Atas Laporan Keuangan. Jakarta: PT. Raja Grafindo Persada.

Harmono. 2011. Manajemen Keuangan. Jakarta: Bumi Aksara.

Hasibuan, Melayu SP. 2004. Dasar-dasar Perbankan. Jakarta: Bumi Aksara.

Hery. 2015. Analisis Laporan

Keuangan.Yogjakarta : CAPS

Kasmir. 2010. Pengantar Manajemen Keuangan. Jakarta: Kencana Prenada Media Group.

Kasmir. 2011. Analisis Laporan Keuangan. Jakarta: PT. Rajagrafindo Persada. 2011. Bank dan Lembaga Keuangan Lainnya. Jakarta: Kencana Prenada Media Group.

Larto. 2012. Koperasipreneur (Jurus Jadi Pengusaha Kaya Anti Bangkrut). Jilid I. Jakarta: Penerbit Nagamedia. 
Martono, Nanang. 2012. Metode Penelitian Kuantitatif. Jakarta: PT. Raja Grafino Persada.

Martono, Harjito. 2001. Manajemen Keuangan. Jakarta: Fakultas Ekonomi Universitas Indonesia.

Munawir. 2012. Analisa Laporan Keuangan. Yogyakarta: Liberty.

Niswonger, C.R., Warren C.S., and Reeve J.M. (1999). Prinsip-prinsip Akuntansi. Jilid I Edisi 19. Jakarta: Erlangga.

Rivai Veithzal. 2013. Manajemen Penkreditan Cara Mudah Menganalisis Kredit. Edisi Revisi. Jakarta: PT. Raja Grafindo Persada.

Riyanto, Bambang. 2012. Dasar-Dasar Pembelanjaan Perusahaan.Yogyakarta: BPFE.

Sarwono. Jonathan. 2006. Analisis Jalur untuk Riset Bisnis dengan SPSS. Bandung: Penerbit Andi.

Subramanyam. 2010. Analisis Laporan Keuangan. Jakarta: Salemba Empat.

Sugiyono.2010. Statistika untuk Penelitian. Bandung: Alfabeta.

Suwardjono. 2005. Teori Akuntansi. Yogyakarta: BPFE.

Suyatno. Thomas, dkk. 2003. Dasar-dasar Perkreditan. Edisi IV. Jakarta: PT. Gramedia Pustaka Utama.
Tahiya. A. Suaib \& Muhammad Hasan. 2010. Koperasi (Pengantar, Sejarah, Idiologi, \& Perkembangannya di Indonesia). Cetakan I, Jilid I. Makassar: Badan Penerbit Universitas Negeri Makassar.

Tiro, Arif Muhammad. 2000. Analisis Regresi dengan Data Kategori. Makassar:Badan Penerbit Universitas Negeri Makassar.

Wegandt, Jerry J. 2007. Accounting Principles. Jakarta: Salemba Empat.

Departemen Koperasi dan Usaha Kecil dan Menengah RI. 2012. Undang-Undang No 17 tahun 2012 tentang Perkoperasian.

Dewan Koperasi Indonesia. Undang-Undang Republik Indonesia No. 25 Tahun 2012 tentang Perkoperasian.

Kementerian Negara Koperasi dan Usaha Kecil dan Menengah. Petunjuk pelaksanaan Kegiatan Usaha Koperasi Jasa Keuangan syariah 2006.

Pramuka, Bambang Agus. 2010. Faktor-faktor yang berpengaruh terhadap Tingkat Profitabilitas Bank Umum Syariah. Jurnal Akuntansi. Universitas Padang. 